\title{
Influence of gonadotrophins on early follicle cell development and early oocyte growth in the immature rat
}

\author{
E. Arendsen de Wolff-Exalto \\ Department of Anatomy, Erasmus University Rotterdam, Rotterdam, The Netherlands
}

\begin{abstract}
Summary. Ovaries of neonatal rats were transplanted on the day after birth into ovariectomized (high gonadotrophin levels) or ovariectomized-hypophysectomized adult female rats (extremely low gonadotrophin levels). Although transplantation caused a reduction of the number of growing follicles in all transplants, it did not seem to induce a clearly abnormal course of follicle development. After 15 days of development, the hormone-rich transplants contained a greater number of follicles larger than type 4 and a smaller number of oocytes with diameters $<21 \mu \mathrm{m}$, than did the hormone-poor transplants. In the transplants with high hormone levels, the smallest follicles (types 2-3a) showed advanced transition of flattened into cuboidal follicle cells and oocyte growth. It is concluded that in these experimental conditions gonadotrophins, presumably especially FSH, seem to have a stimulatory effect on early follicle cell development and early oocyte growth.
\end{abstract}

\section{Introduction}

Various in-vivo and in-vitro studies have concentrated on the influence of gonadotrophins on the development of ovarian follicles (Fainstat, 1968; Eshkol, Lunenfeld \& Peters, 1970; Odor \& Blandau, 1971; Eshkol \& Lunenfeld, 1972; Lintern-Moore \& Pantelouris, 1975; Bachvarova, Baran \& Tejblum, 1980). Little attention has been focussed on the dependence of oocyte growth on gonadotrophins. Arendsen de Wolff-Exalto \& Groen-Klevant (1980) studied oocyte growth rates in immature rats and established that oocytes, although largely growing at a constant rate, may vary their growth rates during the earliest phases of growth. A hormone dependence of early oocyte growth was suggested, growth presumably being faster when gonadotrophin levels are high.

Lintern-Moore \& Moore (1979) proposed that follicle cell factors were responsible for the initiation of oocyte growth in the mouse. They concluded that a crucial point for initiation of oocyte growth is reached when 9 cells surround oocytes in the largest cross-section of follicles: at the 10-cell stage an increase in oocyte diameters became visible whereas at the same time the originally flattened follicle cells had become cuboidal. In view of these observations and the fact that gonadotrophins, especially follicle-stimulating hormone (FSH), influence the structure and function of follicle cells (Eshkol et al., 1970; Baker \& Neal, 1973; Hardy, Danon, Eshkol \& Lunenfeld, 1974), it seemed of interest to study in the rat hormonal influences on (1) the structure and number of follicle cells in very small follicles; (2) early stages of oocyte growth; and (3) the interrelationships between these phenomena. We approached this problem by transplanting neonatal rat ovaries into ovariectomized adult females with or without a pituitary gland. 


\section{Materials and Methods}

Adult Wistar rats of the R-Amsterdam substrain ( 3 months of age, $\sim 200 \mathrm{~g}$ body weight) were ovariectomized in dioestrus under ether anaesthesia, between 09:00 and 10:00 h. In addition, some of these rats were hypophysectomized by the transauricular approach. Between 16:00 and 17:00 $\mathrm{h}$ on the same day, one ovary, randomly taken from a rat born during the preceding night, was implanted under the left kidney capsule of each animal. The other ovary of these donor rats was fixed to determine the developmental stage of the implanted ovaries. The day of transplantation was called Day 1 and the following days were numbered accordingly. At the time of transplantation, blood levels of FSH and LH in the 6 hypophysectomized rats were $<100$ and $<14 \mathrm{ng} / \mathrm{ml}$ respectively, and were high in the 6 non-hypophysectomized rats $(1177 \pm$ 65 and $1747 \pm 70 \mathrm{ng} \mathrm{FSH} / \mathrm{ml}$ and $96 \pm 26$ and $213 \pm 38 \mathrm{ng} \mathrm{LH} / \mathrm{ml}$ at 3 and 10 days after transplantation respectively). In our laboratory intact 16-day-old rats have mean FSH levels of $\sim 1500 \mathrm{ng} / \mathrm{ml}$ and mean LH levels of $\sim 100 \mathrm{ng} / \mathrm{ml}$. Measurements were made by RIA as described by Welschen et al. (1975) and expressed in ng NIAMDD-ratLH/FSH RP-1/ml serum.

At Day 16 (15 days after implantation) the animals were killed, the ovarian transplants were fixed in Bouin's fluid, serially sectioned at $5 \mu \mathrm{m}$ and stained with haematoxylin and eosin. Each cross-section of a follicle with 5 or more cells surrounding the oocyte and with the oocyte nucleolus visible (referred to as the largest cross section) was studied. Oocyte diameters were measured, follicle cell numbers were counted and, for follicles with $<10$ cells, the shape of the cells (flattened or cuboidal) was also recorded. Follicles with $\geqslant 10$ cells ('growing' follicles according to Lintern-Moore \& Moore, 1979; Arendsen de Wolff-Exalto \& Groen-Klevant, 1980 ) contained cuboidal cells only and were classified as types $3 \mathrm{a}$ to 7 according to the number of cells in the largest cross-section (Pedersen \& Peters, 1968). Oocytes in such follicles were classified according to their diameters (see Table 1). When follicles were connected the probable contour of each separate follicle was estimated as accurately as possible. In total 1872 oocytes (follicles) were studied.

In addition, follicle and oocyte populations were established in one ovary of each of five 16-day-old intact immature rats. In every 5th section the largest cross-section of growing follicles was studied as in the ovarian transplants.

For convenience, ovarian transplants in hypophysectomized host animals are referred to as hormone-poor transplants, whereas those in non-hypophysectomized rats are termed hormonerich transplants. Statistical evaluation of the results was carried out using Wilcoxon's test. A difference was considered as significant if the double-tail probability was $\leqslant 0 \cdot 05$.

\section{Results}

The in-situ ovaries of 1-day-old neonatal rats contained many small oocytes and stromal cells, but only an occasional oocyte had a few cells attached to its surface. By 16 days of age in-situ ovaries contained $572.0 \pm 48.0$ follicles with $\geqslant 5$ cells in the largest cross-section. The population of growing follicles consisted of $21 \%$ follicles of type $3 a, 36 \%$ of type $3 b, 26 \%$ of type 4 and $17 \%$ of type $5 \mathrm{a}$. Oocytes in these follicles had diameters of $\leqslant 20 \mu \mathrm{m}$ (in $5 \%$ of the total population), 21-30 $\mu \mathrm{m}$ (18\%), 31-40 $\mu \mathrm{m}$ (28\%), 41-50 $\mu \mathrm{m}(44 \%)$ and 51-60 $\mu \mathrm{m}(5 \%)$. These percentages are comparable to those that may be calculated from the data found for hormone-rich transplants (Table 1).

By 15 days after transplantation the transplants contained several 2-3-layered follicles with oocytes clearly larger than at birth. Follicles in hormone-poor transplants, lying closely together, had contracted granulosa layers, but otherwise the follicles looked normal and several mitotic figures were seen in the granulosa cells. A few thecal cells were sometimes present. 
Table 1. Numbers of follicles and oocytes of rats belonging to certain types and size classes in hormone-rich and hormone-poor ovarian transplants (6/group) 15 days after transplantation

\begin{tabular}{|c|c|c|}
\hline & $\begin{array}{c}\text { Gonadotrophin-poor } \\
\text { transplant }\end{array}$ & $\begin{array}{l}\text { Gonadotrophin-rich } \\
\text { transplant }\end{array}$ \\
\hline \multicolumn{3}{|l|}{ No. of follicles } \\
\hline Type 3a & $20 \cdot 7 \pm 3 \cdot 1$ & $25 \cdot 6 \pm 3 \cdot 9$ \\
\hline Type $3 b$ & $36 \cdot 2 \pm 5 \cdot 0$ & $32.7 \pm 5.4$ \\
\hline Type 4 & $14 \cdot 7 \pm 5 \cdot 8$ & $16 \cdot 3 \pm 4 \cdot 5$ \\
\hline Type $5 a$ & $5.2 \pm 2.8$ & $13 \cdot 0 \pm 3 \cdot 5$ \\
\hline Type Sb & $\overline{0}$ & $5 \cdot 3 \pm 2 \cdot 1\} 23.7+8.7^{*}$ \\
\hline Type 6 & 0 & $5.2 \pm 4.0\}^{23.1 \pm 8.7}$ \\
\hline Type 7 & 0 & $0.2 \pm 0.2$ \\
\hline Total & $76 \cdot 7 \pm 12 \cdot 3$ & $98 \cdot 3 \pm 20 \cdot 4$ \\
\hline \multicolumn{3}{|l|}{ No. of oocytes } \\
\hline$<20 \mu \mathrm{m}$ & $16 \cdot 5 \pm 2 \cdot 3$ & $4 \cdot 2 \pm 0.5^{*}$ \\
\hline $21-30 \mu \mathrm{m}$ & $11 \cdot 8 \pm 2 \cdot 6$ & $21 \cdot 3 \pm 3 \cdot 8$ \\
\hline $31-40 \mu \mathrm{m}$ & $18 \cdot 0 \pm 2.9$ & $30 \cdot 2 \pm 5 \cdot 6$ \\
\hline $41-50 \mu \mathrm{m}$ & $27 \cdot 2 \pm 9.9$ & $40 \cdot 0 \pm 11 \cdot 7$ \\
\hline $51-60 \mu \mathrm{m}$ & $3 \cdot 2 \pm 2 \cdot 0$ & $2.6 \pm 1.9$ \\
\hline
\end{tabular}

Values are mean \pm s.e.m.

* Significantly different from value for these follicle types and oocytes in gonadotrophin-poor transplants, $P<0.05$.

Hormone-rich transplants also contained several follicles with more than 3 layers of cells. Some of the larger follicles had a dented contour, a well developed theca and sometimes showed swollen lutein cell-like cells and deposits in the antrum, as in preovulatory follicles. Polyovular and connected follicles, a not uncommon feature of normal juvenile ovaries (Brambell, 1956; Peters, 1969; Byskov \& Rasmussen, 1973), seemed to be present more often in the ovarian transplants than in in-situ ovaries of 16-day-old animals. No clear signs of atresia were seen in the grafts or the in-situ ovaries.

Follicle and oocyte populations of both groups of ovarian grafts are shown in Table 1 . The total numbers of follicles were not significantly different in the two types of transplants. Hormone-poor transplants contained types $3 \mathrm{a}, 3 \mathrm{~b}$ and 4 follicles $(10-100$ cells in the largest cross-section) and 3 out of 6 ovaries contained 5a follicles (100-200 cells) as well. In contrast, all hormone-rich transplants contained type 5 a follicles and some ovaries also contained types $5 b, 6$ and 7 follicles $(200->600$ cells). The number of follicles larger than type 4 in the latter group was significantly greater than that in hormone-poor transplants.

The number of oocytes with diameters $<21 \mu \mathrm{m}$ was significantly different in the hormone-rich and hormone-poor transplants (Table 1). Although the total absolute numbers of oocytes $\geqslant 21 \mu \mathrm{m}$ in diameter were not different between the two types of transplants, the percentage of these oocytes was $96 \%$ in hormone-rich grafts but only $78 \%$ in hormone-poor grafts $(P<0.05)$. The distribution of oocytes $\geqslant 21 \mu \mathrm{m}$ diameter in the different size classes was, however, comparable in the two types of grafts (Table 1).

In Table 2 the relationship between number and shape of follicle cells and size of the enclosed oocyte in follicles with $<10$ cells in the largest cross-section (follicles smaller than type $3 \mathrm{a}$ ) may be seen. In hormone-rich transplants, follicles with 6 cells contained about 4 cuboidal cells (72\%) whereas in similar follicles in hormone-poor transplants only about 3 cuboidal cells (53\%) were present. A similar difference was seen in follicles with 7 cells: they contained about 6 cuboidal cells $(86 \%)$ in hormone-rich transplants, but only about $5(73 \%)$ in hormone-poor ones. These differences disappeared around the 8-9-cell stages of follicle development and follicles with $>10$ cells contained only cuboidal cells in all ovarian transplants. In hormone-rich transplants, follicles with $>7$ cells enclosed significantly larger oocytes than did those in hormone-poor 
Table 2. Relation of numbers of follicle cells to numbers of cuboidal cells and to diameters of enclosed oocytes, in follicles with $<110$ cells in the largest cross-section in hormone-rich $(+)$ and hormone-poor $(-)$ transplants, 15 days after transplantation

\begin{tabular}{|c|c|c|c|c|}
\hline \multirow{2}{*}{$\begin{array}{l}\text { No. of } \\
\text { follicle cells/ } \\
\text { follicle }\end{array}$} & \multicolumn{2}{|c|}{ No. (\%) of cuboidal cells } & \multicolumn{2}{|c|}{ Oocyte diameter } \\
\hline & - & + & - & + \\
\hline 5 & $2.0 \pm 0.3(40)$ & $2.3 \pm 0.3$ & $12 \cdot 3+0.3$ & $13 \cdot 6+0.3$ \\
\hline 6 & $3.2 \pm 0.1(53)$ & $4 \cdot 3 \pm 0.3^{*}(72)$ & $12.4 \pm 0.1$ & $14.3 \pm 0.5$ \\
\hline 7 & $5.1 \pm 0.2(73)$ & $6.2 \pm 0.2 *(86)$ & $12.9 \pm 0.3$ & $14.3 \pm 0.4$ \\
\hline 8 & $6.8 \pm 0.2(85)$ & $7.2 \pm 0.2 \quad(90)$ & $13 \cdot 0 \pm 0.3$ & $15 \cdot 0 \pm 0.4^{*}$ \\
\hline 9 & $8.6 \pm 0.2(96)$ & $8.9 \pm 0.1 \quad(99)$ & $13.8 \pm 0.4$ & $17.3 \pm 0.6^{*}$ \\
\hline 10 & & & $14.4 \pm 0.3$ & $19.1 \pm 0.8^{*}$ \\
\hline 11 & & & $16.4 \pm 0.7$ & $21.2 \pm 0.7^{*}$ \\
\hline 13 & & & $16.6 \pm 0.7$ & $23.6 \pm 0.7 *$ \\
\hline 15 & & & $19.2 \pm 0.7$ & $24.1 \pm 0.6^{*}$ \\
\hline 17 & & & $23 \cdot 3 \pm 1.2$ & $26.7 \pm 0.9^{*}$ \\
\hline $20 / 21$ & & & $28.4 \pm 1 \cdot 1$ & $32.1 \pm 0.9$ \\
\hline $23 / 27$ & & & $31.1 \pm 1.0$ & $36 \cdot 2 \pm 1 \cdot 1$ \\
\hline $28 / 32$ & & & $35 \cdot 3 \pm 1 \cdot 1$ & $39.1 \pm 1.1$ \\
\hline $38 / 42$ & & & $38.3 \pm 1.1$ & $40 \cdot 1 \pm 1.0$ \\
\hline $58 / 62$ & & & $44.0 \pm 1.1$ & $41.8 \pm 0.9$ \\
\hline $90 / 100$ & & & $46.6 \pm 0.7$ & $42.8 \pm 0.6$ \\
\hline
\end{tabular}

Four to six transplants of each group were studied. Data on numbers of cuboidal cells and/or oocyte diameters are means \pm s.e.m. based on counts and measurements on 24-34 follicles for each type of follicle with 5-9 cells and on 14-44 follicles for each type of follicle with $\geqslant 10$ cells.

* Significantly different from hormone-poor $(-)$ value, $P \leqslant 0.05$.

transplants. However, when follicles showed 20 or more cells, these differences between oocyte sizes of the two types of grafts were no longer significant and disappeared completely (Table 2).

\section{Discussion}

Transplantation of neonatal ovaries resulted in a marked reduction of follicles but did not induce a clearly abnormal course of follicle development. The transplants of both groups developed under largely comparable conditions, except for continuous exposure to low or high levels of pituitary hormones. The experiments of Eshkol \& Lunenfeld (1972) and Uilenbroek, Arendsen de Wolff-Exalto \& Welschen (1976) show the importance, by the 2nd week of life, of gonadotrophins for follicle development in the ovaries of mice and rats with an intact pituitary. Therefore, in our interpretation of the present results we have only taken into consideration the difference in gonadotrophin exposure of the transplants.

In the host animals with ovariectomy only, gonadotrophin levels, especially those of FSH, were similar to those of immature females around Day 16. These high gonadotrophin levels may be responsible for the greater number of advanced follicles with larger follicle cells and for thecal cell proliferation in the hormone-rich transplants. On the other hand, the presence in the hormone-poor transplants of smaller follicles with crowded granulosa cells is in accordance with other histological data on ovaries not exposed to gonadotrophins (Eshkol et al., 1970; Eshkol \& Lunenfeld, 1972; Baker \& Neal, 1973; Lintern-Moore \& Pantelouris, 1975). It may be concluded that the approach used in this study created hormonal environments which were sufficiently different to induce clear differences in follicle growth, and this approach to study the gonadotrophin dependence of early oocyte growth seems suitable. 
Our results indicate that in both types of grafts the smallest follicles studied had mainly flattened cells. Also, in both types of grafts, in follicles with increasing numbers of cells, higher percentages of cuboidal cells and oocytes with greater diameters were found. Both phenomena seemed to be stimulated by gonadotrophins, since in hormone-rich transplants small follicles with a specific number of cells showed a higher percentage of cuboidal cells and contained larger oocytes. Gonadotrophins may influence oocyte growth directly or indirectly mediated by the follicle cells (Lintern-Moore \& Moore, 1979). In the latter case, the higher percentages of cuboidal cells in follicles with a specific number of cells, as found in the hormone-rich transplants, might be responsible for the more advanced oocyte growth observed. However, oocyte sizes in larger follicles, those with $\geqslant 20$ cells, were not different in the two types of grafts. At this stage oocytes have grown beyond the size of $25 \mu \mathrm{m}$ and may have entered a hormone-independent growth phase as suggested for comparable oocytes in in-situ ovaries at Days 16 and 28 (Arendsen de Wolff-Exalto \& Groen-Klevant, 1980). The present findings indicate that the different growth rates of oocytes smaller than $\sim 25 \mu \mathrm{m}$ in in-situ ovaries of 16 and 28-day-old rats are due to the difference in gonadotrophin levels, especially those of FSH, present at these ages (Meijs-Roelofs, Uilenbroek, de Jong \& Welschen, 1973).

Comparison of the oocyte populations of hormone-poor and hormone-rich transplants revealed a markedly smaller number of oocytes $<21 \mu \mathrm{m}$ in the latter. This was presumably due to the very small oocytes in hormone-rich transplants growing at fast growth rates through the early growth stages. This view is in accordance with the higher percentage of oocytes $\geqslant 21 \mu \mathrm{m}$ which was present in oocyte populations of hormone-rich transplants. The finding that early oocyte growth is enhanced under conditions of high gonadotrophin levels is in agreement with our previous findings of differences in early oocyte growth rates observed between 16- and 28-day-old intact rats (Arendsen de Wolff-Exalto \& Groen-Klevant, 1980). The results of our study indicate that, under the experimental conditions given, gonadotrophins, presumably especially FSH, have a stimulatory effect on early follicle cell development and early oocyte growth.

Our observations therefore show that, although influencing each other, the oocyte and follicle components grow with a certain independence. Initially, in small follicles with $<21$ cells in the largest cross-section, the shapes of follicle cells (possibly related to follicle cell activity) and oocyte growth seem to be interrelated and influenced by gonadotrophins. In later stages of growth, however, oocytes grow independently of hormone conditions, whilst gonadotrophins markedly influence multiplication rates of follicle cells, as is shown by our findings of a greater number of follicles of types $\geqslant 5 \mathrm{a}$ in ovarian transplants in a gonadotrophin-rich environment.

I thank Dr R. Welschen for ovariectomies and hypophysectomies of rats and transplantations of ovaries; Dr J. Th. J. Uilenbroek for measurements of gonadotrophins; Dr H. M. A. Meijs-Roelofs and Dr J. Moll for valuable criticism during the preparation of the manuscript; and Ms E. Klink for typing the manuscript.

\section{References}

Arendsen de Wolff-Exalto, E. \& Groen-Klevant, A.C. (1980) Oocyte growth in the immature rat. $J$. Reprod. Fert. 59, 187-192.

Bachvarova, R., Baran, M.M. \& Tejblum, A. (1980) Development of naked growing mouse oocytes in vitro. J. exp. Zool. 211, 159-169.

Baker, T.G. \& Neal, P. (1973) Initiation and control of meiosis and follicular growth in ovaries of the mouse. Annls Biol. anim. Biochim. Biophys. 13, 137-144.
Brambell, F.W.R. (1956) Ovarian changes. In Marshall's Physiology of Reproduction, 3rd edn, Vol. 1, Part 1, pp. 453-454. Ed. A. S. Parkes. Longmans Green, London.

Byskov, A.G. \& Rasmussen, G. (1973) Ultrastructural studies of the developing follicle. In The Development and Maturation of the Ovary and its Functions, pp. 55-62. Ed. H. Peters. Excerpta Medica, Amsterdam.

Eshkol, A. \& Lunenfeld, B. (1972) Gonadotropic regu- 
lation of ovarian development in mice during infancy. In Gonadotropins, pp. 335-346. Eds B. B. Saxena, C. G. Beling \& H. M. Gandy. J. Wiley \& Sons Inc., New York.

Eshkol, A., Lunenfeld, B. \& Peters, H. (1970) Ovarian development in infant mice. Dependence on gonadotropic hormones. In Gonadotrophins and Ovarian Development, pp. 249-258. Eds W. R. Butt, A. C. Crooke \& M. Ryle. Williams \& Wilkins, Baltimore.

Fainstat, T. (1968) Organ culture of postnatal rat ovaries in chemically defined medium. Fert. Steril. 19, 317-338.

Hardy, B., Danon, D., Eshkol, A. \& Lunenfeld, B. (1974) Ultrastructural changes in the ovaries of infant mice deprived of endogenous gonadotrophins and after substitution with FSH. J. Reprod. Fert. 36, 345-352.

Lintern-Moore, S. \& Moore, G.P.M. (1979) The initiation of follicle and oocyte growth in the mouse ovary. Biol. Reprod. 20, 773-778.

Lintern-Moore, S. \& Pantelouris, E.M. (1975) Ovarian development in athymic nude mice. II. The growth of the oocyte and follicle. Mech. Ageing Develop. 4, 391-398.
Meijs-Roelofs, H.M.A., Uilenbroek, J.Th.J., de Jong, F.H. \& Welschen, R. (1973) Plasma oestradiol-17 $\beta$ and its relationship to serum follicle-stimulating hormone in immature female rats. J. Endocr. 59, 295-304.

Odor, D.L. \& Blandau, R.J. (1971) Organ cultures of fetal mouse ovaries I. Light microscopic structure. Am. J. Anat. 131, 387-414.

Pedersen, T. \& Peters, H. (1968) Proposal for a classification of oocytes and follicles in the mouse ovary. J. Reprod. Fert. 17, 555-557.

Peters, H. (1969) The development of the mouse ovary from birth to maturity. Acta endocr., Copenh. 62, 98-116.

Uilenbroek, J.Th.J., Arendsen de Wolff-Exalto, E. \& Welschen, R. (1976) Studies on the significance of the high levels of follicle stimulating hormone for follicular development in immature rats. Annls Biol. anim. Biochim. Biophys. 16, 297-305.

Welschen, R., Osman, P., Dullaart, J., de Greef, W.J., Uilenbroek, J.Th.J. \& de Jong, F.H. (1975) Levels of follicle-stimulating hormone, luteinizing hormone, oestradiol-17 $\beta$ and progesterone, and follicular growth in the pseudopregnant rat. J. Endocr. 64, $37-47$.

Received 1 February 1982 